\title{
Two New Starrs Relating to the History of Merton College, Oxford ${ }^{*}$
}

\author{
Peter E. Pormann \\ Merton College, Oxford
}

\section{Custodi sociisque \\ Collegii Mertoniensis \\ in Academia Oxoniensi}

$\mathrm{T}$ he early history of the University of Oxford, and more particularly of Merton College, is intimately linked to the history of the Jews in England before their expulsion in $1290 .{ }^{1}$ This link is especially evident in the starrs, or deeds of conveyance, which date from this period. A. Neubauer has already published the Hebrew text of three of these documents relating to land purchases made by the Founder of Merton College, Walter de Merton. ${ }^{2}$ By a quirk of fate, I have come across two hitherto unknown starrs, or deeds of conveyance, relating to the early history of the college which I propose to edit and translate here. I originally found these starrs in an eighteenth century copy (with Latin translation) in a manuscript in St John's College, Oxford; ${ }^{3}$ they were made by J. Gagnier (1670?-1740) who became the Lord Almoner's Professor of Arabic in Oxford in $1724 .{ }^{4}$ These documents, along with a Latin deed of conveyance relating to the same transaction, provide interesting evidence about the part the Jewish community of Oxford played in the earlier days of the oldest university in England.

Since the starting point of my enquiry were Gagnier's papers in St John's which led me to try to unearth the originals, I begin my discussion with the material history of these starrs in section I. Following that, I shall edit and translate the Hebrew text and discuss some linguistic features (II). I also transcribe the Latin translation of them made by Gagnier (III). In IV, I shall present an edition and translation of a Latin deed relating to the same transaction. Finally I shall discuss these texts in their historical context (V). The purpose of this paper is twofold: to tell the history of the Hebrew documents themselves, and to show what contribution these documents can make to the history of the Jews in Oxford in the thirteenth century. Sections I and III serve the former purpose, while sections II, IV and V try to achieve the latter.

* I would like to thank J. Barton, J. Dueck, Dr J. R. L. Highfield, Dr M. M. N. Stanfield, and Dr T. Stern, as well as the anonymous referees for their comments on earlier drafts of this article; I record my gratitude to the Warden and Fellows of Merton College, Oxford, and the President and Fellows of St John's College, Oxford, for their permission to publish the documents edited here for the first time.

1 Cf. C. Roth, The Jews of Medieval Oxford (Oxford Historical Society, Oxford, 1951), ch. 7.

2 Jewish Quarterly Review 2 (1911), pp. 527-30.

3 St John's College Oxford, MS No. 253, item 51. Cf. E. Savage-Smith et al., The Oriental Manuscripts of St John's College, Oxford, A Catalogue of Oriental Manuscripts in the Colleges of the University of Oxford, vol. 1 (Legenda Press, Oxford, forthcoming 2004).

${ }^{4}$ DNB 20.358-59. 
In order to understand how the life of the two Hebrew starrs discussed here differs from those published by Neubauer, ${ }^{5}$ it is necessary to describe how they were stored and catalogued. Today, the 'Neubauer' documents, which are held in the collections of Merton College, share one physical characteristic: they are stitched to Latin deeds relating to the same transaction. The stitching must have been done at quite an early date, maybe straight after the drafting of these documents, or in 1287-1288 when a college clerk produced a liber ruber containing 'summaries of at least 358 charters or deeds' ${ }^{6}$ which the college possessed. Not only were the Hebrew and the Latin deeds stitched together, they were also formally linked by an identical Latin letter inscribed at the bottom or on the verso of each parchment. These letters indicated where the document was stored, since each letter referred to a pyx (or box) kept in the college archive and recorded in the liber ruber. For example the Hebrew deed no. 2423 has an $R$ in blue ink on it which appears in the same ink and hand on the corresponding Latin deed. Similarly, an $M$ is used to mark both the Latin and Hebrew parts of document no. 1146. In both cases, the Latin and the Hebrew documents are folded and stitched together, and subsequently kept in the pyx $R$ and $M$ respectively.

Unlike those edited by Neubauer, the two starrs in question here were at some stage separated from their Latin counterpart: they have separate shelfmarks and are kept in different places in Merton College archives. The Hebrew deeds have the shelfmark Merton College, Oxford, Archives, D.1.58 (i), while the shelfmark of the Latin deed is no. 2349. In spite of their currently separate locations, there is some convincing evidence that they were originally kept together. Given this, it is interesting not only to describe these documents but also to try to unravel why and how they were separated.

The two Hebrew starrs are written on a relatively small piece of parchment $\left(15 \times 13 \mathrm{~cm}^{2}\right)$ : the text of the first deed takes up $5 \times 12.5 \mathrm{~cm}^{2}$ and the text of the second $3.5 \times 12 \mathrm{~cm}^{2}$. There is a space of $1 \mathrm{~cm}$ between the two deeds. The Hebrew script is extremely small, significantly smaller than that of the 'Neubauer' starrs mentioned above; most letters hardly rise to the height of $1 \mathrm{~mm}$. Both starrs are rendered in a medieval cursive hand, and are autographed by Josce, son of Bendit. The original station in the journey of this Hebrew parchment was almost certainly the pyx labelled $V$ which also contained the Latin document no. 2349. Both the Hebrew and the Latin documents are labelled with an identical red letter $V$, and the entry in the liber ruber of 1288 shows quite clearly that they were kept together in pyx $V:^{7}$

Carta Willelmi de Leycestre facta domino Waltero de Merton et post decessum ipsius Walteri domui scolarium de Merton de tota terra sua in Gamelegeye et de aduocatione medietatis ecclesie eiusdem uille. exceptis xviii denarios reddi-

5 (As in n. 5.)

6 J. R. L. Highfield, The Early Rolls of Merton College Oxford (Oxford Historical Society, Oxford, 1964), p. 366.

7 Merton College, Oxford, Archives 1.1 (liber ruber), fo $19^{\mathrm{r}}{ }_{9-15}$. The text in italics is by second hand which must be nearly contemporaneous with the first. 
tus quos Primula soror ipsius Willelmi ei reddere solebat. et homagio Paschasii fratris predicti Willelmi. et sex acris terre quas ad opus fratris ipsius idem Willelmus retinuit. et est duplicata. cum quodam starris in carta et reponitur in $V$.

A deed by William of Leicester, made to Walter de Merton and after the latter's death to the House of the Scholars of Merton about all his [i.e. William's] land in Gamlingay and half the advowson of the church of the same village; except 18 pence rent which Primula, the sister of the same William, used to pay him [i.e. William] and the homage of Paschasius, the brother of the aforementioned William and six acres of land which William kept for the use of his brother. There is a duplicate. With some starrs in the deed. It is stored away in [pyx] $\mathrm{V}$.

Thus the Latin deed had been wrapped around the Hebrew piece of parchment, and although the latter is flattened now, one can still see the folds which bear witness to its original location.

The Hebrew starrs were subsequently separated from their Latin counterpart, and found their way to the desk of J. Gagnier, a prominent Hebrew and Arabic scholar in Oxford ${ }^{8}$ in the first half of the eighteenth century, who copied and translated them. His transcription and translation are item 51 (fos 61-65) in the manuscript 253 in St John's library, Oxford. This manuscript is a collection of curiosities: pages from books in Oriental languages, drawings, notes and so forth which John Pointer (1668-1754), sometime chaplain of Merton, bequeathed to St John's. ${ }^{9}$ Each of the Hebrew deeds is carefully copied, presumably from the original, by J. Gagnier, and then translated by him into Latin. On fo $61^{\mathrm{r}}$ Gagnier entitles theses papers as follows:

The Copy of a Hebrew Conveyance of Land in Gamlingay from William of Leicester, to Walter de Merton, the Founder of Merton College, Oxon. In $y^{\mathrm{e}}$ time of K. Hen. $3^{d}$. The Founder purchasing Land of a Jew, The Jew wou'd have $y^{\mathrm{e}}$ Leases drawn in his Own Language. These Leases now translated into Latin by M. Gagnier.

Gagnier wrote the text and his translation on sheets of paper which are ruled for the Hebrew. His hand in Hebrew is clear and that of a Western scholar, showing little or no signs of cursiveness. When these pages were written is not entirely clear. Gagnier came to Oxford in 1703 and died in $1740 ;{ }^{10}$ when and why during this period he wrote them is anybody's guess. His overall command of Hebrew is good, although we find some minor errors and omissions in both the transcription and the translation. ${ }^{11}$

8 See n. 4 above, and n. 10 below.

9 J. Pointer, Oxoniensis Academia, or the Antiquities and Curiosities of the University of Oxford (S. Birt and J. Ward, London, 1749), pp. 92-94. Cf. also the unpublished typescript, Coxesupplement, p. 12; on Pointer cf. $D N B$ 46.17-18, and V. H. H. Green, 'University and Social Life', in T. H. Aston (ed.), The History of the University of Oxford, vol. 5: The Eighteenth Century (Oxford University Press, Oxford, 1986), ch. 11, pp. 309-58, p. 350 and n. 4.

10 Cf. DNB 20.358-59. Cf. D. Patterson, 'Hebrew Studies', in Aston, The History of the University of Oxford, vol. 5, ch. 18 (pp. 535-50), pp. 541-42.

11 Cf. Th. Hearne, Remarks and Collections, vol. 2, ed. by C. E. Doble (Oxford Historical Society, Oxford, 1886), p. 308: ' $\mathrm{M}^{\mathrm{r}}$. Gagnier, a French Gentleman, ... is now [sc. 14 November 1709] a Teacher of $y^{\mathrm{e}}$ Hebrew Language in Oxford, and is esteem'd by able Judges to be a compleat Master of it ...'? 
The Hebrew deeds must have returned to Merton shortly thereafter. At least 20 years after Gagnier's death, John Fowell (1725-1803), who was the chaplain of Merton in 1750 and was awarded a $D D$ in $1762,{ }^{12}$ sent our Hebrew deeds together with an undated letter to Joseph Kilner (1721-1793). ${ }^{13}$ The content of the letter is as follows: ${ }^{14}$

Addressed to: The Rev'd Mr Kilner, Fellow of Merton College, Oxford.

Imprimis is $\mathrm{D}^{\mathrm{r}}$ Kennicot in Oxford? if not be pleased to return the enclosed by the bearer. If he is could you get him to translate it for me either into Latin or English? - and let me have again whilst you are here. It is supposedly a Jewish Starr or Acquittance respecting the Conveyance of an Estate at Gamlingay in Cambridgeshire from Will. de Leycester to our Founder and to his College after him-upon $w^{\text {ch }}$ the Jew had before some demand. It was made I believe anno 52. Hen. III. that is in the year 1267. or 1268 .

The Doctor will be pleased to be very exact as to the style of our Founder if he is (as I suppose he is) mentioned in it whether as Gir Gautier de Merton $\& c$., and likewise as to the date if there is any.

Rev. Dr. Fowell

The ' $\mathrm{D}^{\mathrm{r}}$ Kennicot' mentioned in the letter is the Benjamin Kennicott (17181783), who achieved fame through his work on the textual tradition of the Hebrew bible, of which he produced a number of important editions. ${ }^{15} \mathrm{He}$ must have 'been in Oxford' at the time when Kilner received the letter, because the Hebrew deeds stayed in his possession. It was only in 1966 after Lambeth Palace bought his bequest that they came back to Merton. The librarian Dr Bill found the piece of parchment together with the letter, and returned them to the college, where they are kept today.

\section{II}

In the first deed, Josce, son of Bendit declares that money which William of Leicester owed him (Josce), is now owed to Walter de Merton. The history of the debt is as follows: William of Leicester owed the money to Abram, son of Vives. This Abram was married to a woman called Esther (אסתר) in the first, and אונטייר (perhaps 'Ontier'?) in the second deed. This Abram must have died while the debts were not yet paid back. His wife Esther married again. Her new husband, Josce, son of Bendit, received the debts as part of the dowry. There were two debts, the first for $£ 43$ which was payable at Christmas 1263, and the second for 16 mark which was payable one year earlier, at Christmas 1262. The first deed is dated 23 May 1268, and was witnessed by Josce's son Bendit, and a Chayim de Nikol (i.e. Lincoln).

The text of the first deed runs as follows: ${ }^{16}$

12 Cf. J. Foster, Alumni Oxonienses, 4 vols (vol. 1: J. Foster, London, 1888; vols 2-4: J. Parker, Oxford, 1888), p. 484.

13 Cf. J. R. L. Highfield and G. H. Martin, History of Merton College (Oxford University Press, Oxford, 1997), p. 243.

14 Merton College, Oxford, Archives, D.1.58 (ii).

15 DNB 31.10-12, Patterson, 'Hebrew Studies' (as in n. 10 above), pp. 540-41.

16 Merton College, Oxford, Archives, D.1.58 (i), lines 1-16; the copy by J. Gagnier is contained in St John's College Oxford, MS No. 253, item 51, fo $62^{v_{1}-62^{\mathrm{v}} \text { ult. }}$. 
אני חתום מטה מודה הודאה גמורה שמכרתי והנחתי ממני ומיורשי

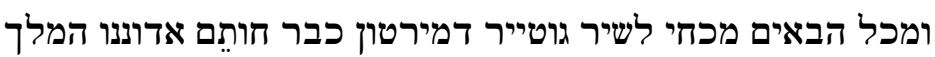

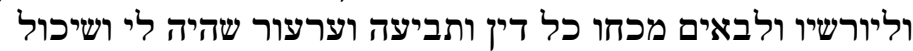

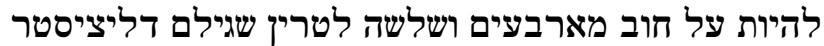

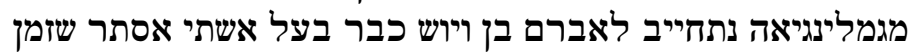

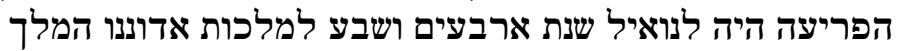

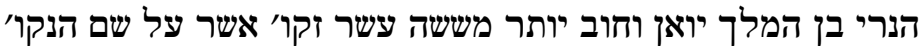

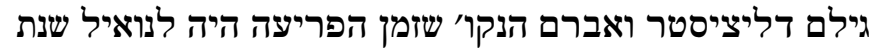

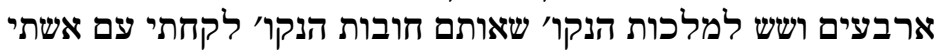

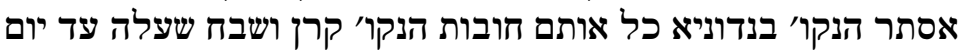

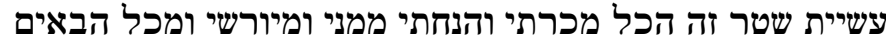

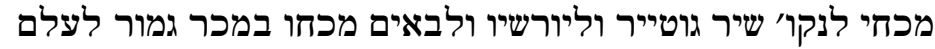

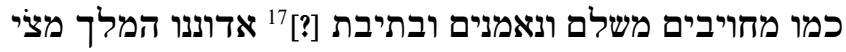

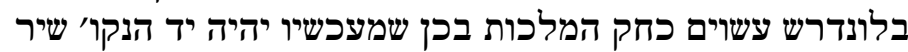

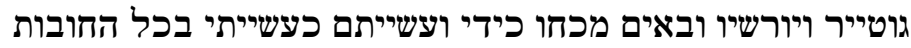

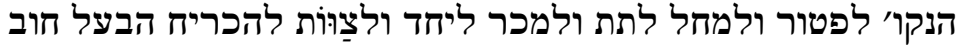

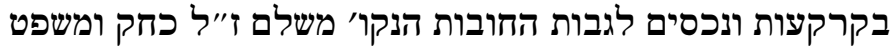

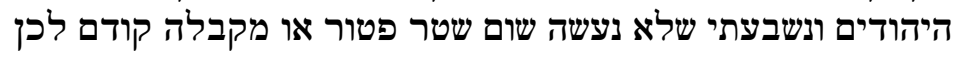

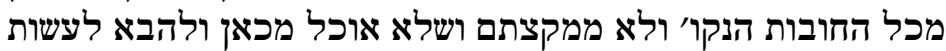

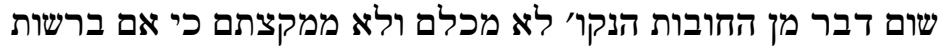

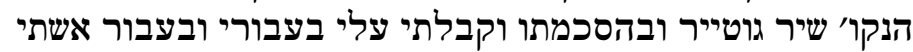

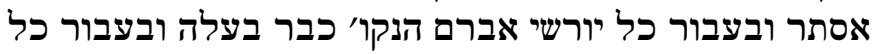

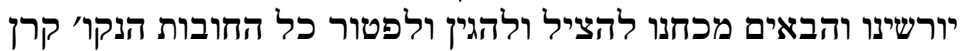

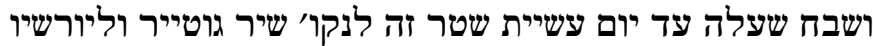
ולבאים מכחו נגד כל יהודי ארץ אי איש או אשה ונגד כל אדיר וליר וריור

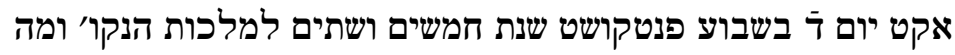

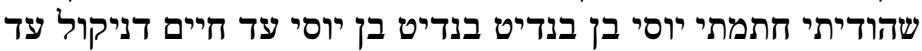

Translation of the first Hebrew deed:

I signing below make an irrevocable pledge that I have sold and transferred from myself, my heirs and all my assigns to Sir Gautier [i.e. Walter] de Merton, former chancellor of our Lord, the King, and to his heirs and his assigns any right, claim, and appeal, which I had or could have regarding the debt of forty three pounds which William de Leicester from Gamlingay owed to Abram son of Vives, former husband of my wife Esther; the time of payment was Christmas, the forty seventh year of the reign of our Lord, King Henry [III], son of King John. And [another] debt, sixteen mark, which is in the name of the aforementioned William de Leicester and the aforementioned Abram; the time of payment was Christmas, the forty sixth year of the aforementioned reign. I have

17 Gagnier started a new paragraph in his copy, and left this word out. His translation has iuxta edictum. 
received the same aforementioned debts, together with my aforementioned wife Esther, in dowry; all the same debts - capital and interest which accrued to the day of making this contract - all this I have irrevocably and forever sold and transferred from myself, my heirs, and my assigns to the aforementioned Sir Gautier [i.e. Walter de Merton], his heirs and his assigns; [I have done this] like someone who has an absolute claim to a debt and is faithful, and according to the order [?] of our Lord, the King, the liberator [?], made in London according to the law of the kingdom. So that from now on the control $[y \bar{a} d]$ of the aforementioned Sir Gautier [i.e. Walter de Merton], his heirs and his assigns shall be completely like mine, and their action concerning the aforementioned debts shall be completely like mine with regard to acquitting and remitting; giving and selling; allocating and ordering; and compelling the debtor [sc. to pay] both capital and moveable goods and collecting the aforementioned debts; that is to say, in accordance with the law and judgement of the Jews, and I swear that no other receip $\mathrm{t}^{18}$ or quitclaim has been made previously regarding the aforementioned debts, in whole or in part; nor shall I be able from now on and in the future to make any arrangement regarding the aforementioned debts, in whole or in part, unless it is with the authority and permission of the aforementioned Sir Gautier [i.e. Walter de Merton]. I agree and take it upon me-for myself and my wife Esther, for all the heirs of the aforementioned Abram, her former husband, and for our heirs and our assigns - to safeguard, defend, and acquit all the aforementioned debts, capital and interest accrued to day, to the aforementioned Sir Gautier [i.e. Walter de Merton], his heirs, and his assigns against the Jews of the 'Island land' ${ }^{19}$ man or woman, and everybody [else]. Act' [i.e. actum 'made'] Wednesday, the Week of Pentecost [Whitsun], in the fifty second year of the aforementioned reign. I have signed what I have pledged, I, Josce, son of Bendit [Yōsì ben Bendīt ]; Bendit, son of Josce, [Bendīt ben Yōsī; i.e. the son of the former], witness; Chayim [Haiyim ] de Nikol [i.e. Lincoln], witness.

The second deed deals with the land mortgaged as security for these debts. Josce, son of Bendit, declares that he transfers to Walter de Merton his title to the land in Gamlingay (Cambridgeshire) and all the appurtenances previously mortgaged to Abram, son of Vives, and first husband of Esther. This deed is undated, but signed by the same two witnesses and written on the same piece of parchment, and therefore it is safe to assume that they were drafted at the same time.

The text of the second deed runs as follows: ${ }^{20}$

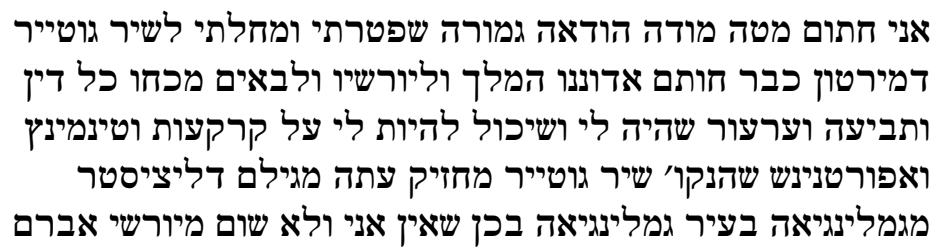

\footnotetext{
18 שטר פטור; cf. M. D. Davis, שטרות, Hebrew Deeds of English Jews Before 1290 (Office of the Jewish Chronicle, London, 1888), p. xi.

19 In Hebrew: ארץ אי, presumably a term to denote England, maybe due to a popular etymology.

20 Merton College, Oxford, Archives, D.1.58 (i), lines 17-28; the copy by J. Gagnier is contained in St John's College Oxford, MS No. 253, item 51, fo $64 \mathrm{r}_{1}$ ff.
} 


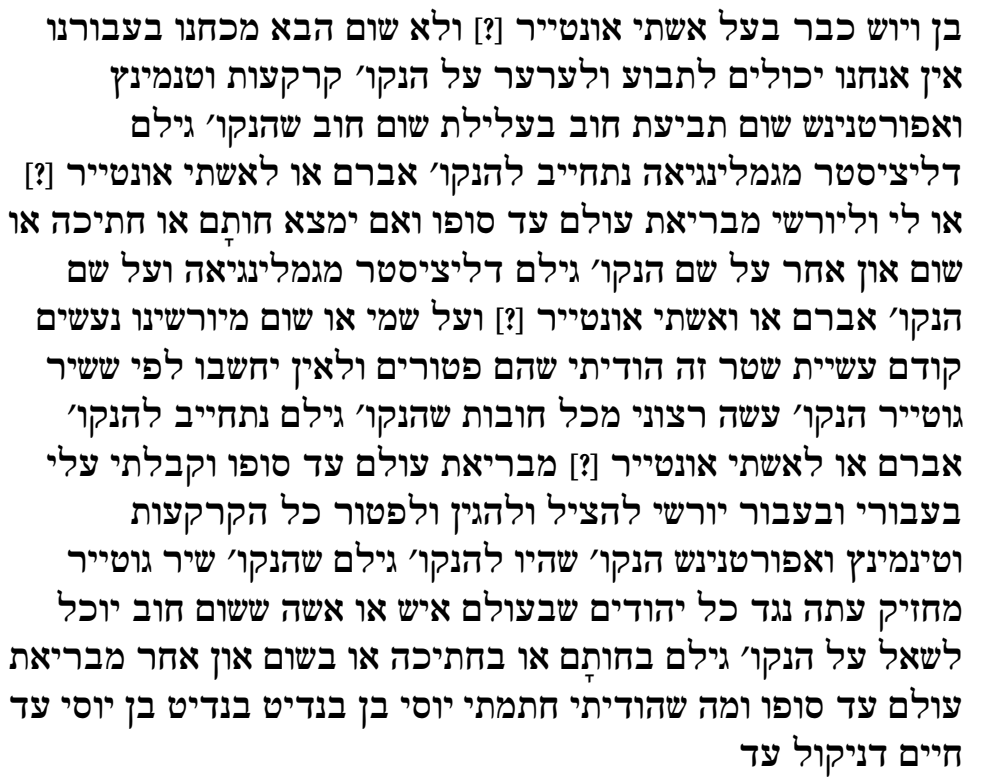

Translation of the second Hebrew deed:

I signing below make an irrevocable pledge that I have acquitted and remitted to Sir Gautier [i.e. Walter] de Merton, former chancellor of our Lord, the King, and to his heirs and his assigns any right, claim and appeal which I had or could have regarding the capital, tenements, and appurtenances which the aforementioned Sir Gautier [i.e. Walter de Merton] now holds from William de Leicester in the village of Gamlingay. Henceforce neither I nor any of the heirs of Abram, son of Vives, [former] husband of my wife Ontier [?], nor any of our assigns; none of us can lay claim to, or appeal against [the conveyance of] the aforementioned capital, tenements, and appurtenances in any way, not [even] by [producing] a deed of any debt which the aforementioned William of Leicester and Gamlingay owed to the aforementioned Abram or my wife Ontier [?], or to myself and my heirs, from the creation to the end of the world. As for any bond, portio [of a deed ${ }^{21}$ ], or any other instrument in the name of the aforementioned William de Leicester and Gamlingay, and in the name of the aforementioned Abram or my wife Ontier [?], and in my name or that of any of our heirs is found, which was made before this deed, I pledge that it is null and void, and let it count for nothing. For the aforementioned Sir Gautier [i.e. Walter de Merton] has done as I wished with all the debts which the aforementioned William [de Leicester] owed to Abram or my wife Ontier [?], from the creation to the end of the world. I took it upon me-for myself and my heirs - to safeguard, defend, and acquit all the aforementioned capital, tenements, and appurtenances, which the aforementioned William [formerly] possessed, and which the aforementioned Sir Gautier [Walter de Merton] now holds, against all Jews in the world, man or woman, so that they cannot ask for any debt from the aforementioned William, in the bond, portio, or any other instrument from the creation to the end of the world. I have signed what I pledge, I, Josce, son of Bendit [Yōsi

21 Davis, שטרות, Hebrew Deeds (as in n. 18 above), p. xi. 
ben Bendīt ]; Bendit, son of Josce, [Bendīt ben Yōsī; i.e. the son of the former], witness; Chayim (Haiyìm) de Nikol [i.e. Lincoln], witness.

The two texts contain some interesting linguistic features that are worth noting. On the level of morphology, the texts presented here have many of the hallmarks typical of insular documents of the thirteenth century described by Davis in his work שטרות, Hebrew Deeds of English Jews Before $1290 .^{22}$ I can mention but a few of them here: ' is often written plene, while "' is used to ren-

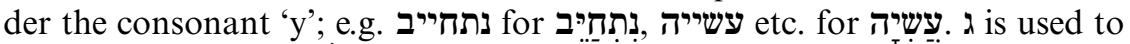
transliterate 'w'; e.g. גילם for 'William' (maybe under the influence of French 'Guillaume'). Christian holidays are transliterated rather than translated; e.g. נאיל or for noël (i.e. Christmas, the Hebrew translation being נואיל הגומת המולד); פנטקושט for pentecoste (i.e. 'Whitsun', Hebrew שבועות). Some English technical legal terms have standard translations; e.g. חבותם for 'bond'; חתותם מתיכה for 'portio' [sc. of a bond]; cf. also ליטרא ליטרין for 'pound'. Four abbrevi-

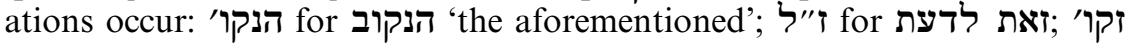

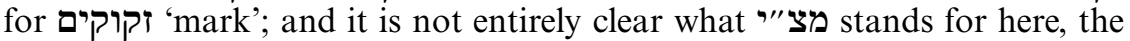
normal meaning of משיח צדקנו not making much sense; Gagnier translated this last abbreviation as 'liberator'.

Moving on from morphology to syntax, we find, again, some shared typical features in these two deeds. One is a large amount of repetition and redundancy in order to achieve precision and avoid ambiguity. Examples of repetition abound in these two deeds. Hendiadys like דין ותביעה, יורשינו והבאים שהיה לי ושיכול להיות etc. is frequent; cumbersome expressions such as מכחנו

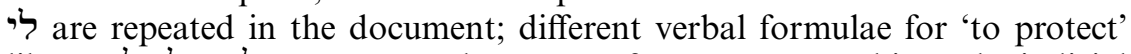
like להציל ולהגיין occur more than once. If one compares this to the judicial terminology of the Latin deed transribed in section IV below, one can see that many of the legal formulae and syntactical structures in the Hebrew have counterparts in the Latin.

\section{III}

As we have seen in the first part of the present contribution, the parchment containing the Hebrew documents edited above interested a number of Oxonian Hebraists during the eighteenth century. This was a time when Hebrew Studies emancipated themselves from the subject of divinity, with which they were closely linked. ${ }^{23}$ The most prominent scholar of the time was B. Kennicott, in whose possession the parchment with the two starrs ended up. ${ }^{24}$ Kennicott studied the text of the Hebrew bible keenly, and unlike many of his contemporaries, published his findings in books such as the one entitled The Ten Annual Accounts of the Collation of Hebrew Mss of the Old Testament; Begun in 1760, and Compleated in $1769 .{ }^{25} \mathrm{~J}$. Gagnier, who was the first

22 As in n. 18 above, pp. ix-xv.

23 Cf. Patterson, 'Hebrew Studies' (as in n. 10 above).

24 See p. 105 above.

25 (Oxford, 1770). 
to translate the two starrs into Latin, was a less prominent figure than Kennicott. Yet his Latin translation is an interesting testimony to the study of Hebrew at Oxford in the eighteenth century. It runs as follows.

\section{First Deed: ${ }^{26}$}

Ego infra scriptus confiteor confessione perfectâ me vendidisse et concessisse a me \& ab hæredibus meis et a posteris meis Sir Waltero (Heb. Gautier) de Merton, quondam Cancellario Domini nostri Regis, et hæredibus eius, et posteris eius totum ius \& postulationem et prætentionem, quæ erat mihi \& potuit esse super debitum quadraginta et trium librarum, quas Willelmus de Leicestre de Gamelegaye debebat Abramo filio Vives (or Vios) quondam marito Asty Mister; quarum solutionis tempus fuit ad Noel (Natale Domini) Anni quadragessimi septimi regni Domini nostri Regis Henry filii Joan. Item debitum plusquam sexdecim לט librarum quod mihi debetur nomine supradicti Willelmi de Leicestre, \& Abrami suprad[ict]i cuius tempus solutionis fuit ad Noel anni quadragessimi sexti regni supradicti. Quae debita supradicta accepi cum Asti Mister supradicta cum dota sponsali eius. Omnia hæc debita supradicta tam capitale, quam lucrum quod emersit adusque diem facti contractus huius, omnia vendidi et concessi a me $\&$ ab hæredibus meis, $\&$ a posteris meis supradicto Sir Waltero \& hæredibus eius \& posteris eius venditione perfecta in perpetuum instar eorum qui obligati sunt a sæculo, \& sunt fideles, \& iuxta edictum Domini nostri Regis Liberatoris in Londres factum, secundum ius Regni. Ita ut in posterum sit manus supradicti Sir Walteri \& Hæredum eius \& Posterorum eius sicut fuit manus mea, $\&$ actio eorum sicut actio mea erga omnia debita supradicta, ut possit dimittere, cedere, dare, vendere, $\&$ iubere $\&$ cogere debitorem tam in fundis, quam in bonis mobilibus ad exigenda debita supradicta. Perficiam hoc verbum meum iuxta legem \& iudicium Iudaeorum. Et iuravi nullum alium antea factum esse contractum de omnibus debitis supradictis, necque in toto, neque in parte, neque in hoc præsenti, vel in futurum tempus posse quicquam disponi ex debitis istis supradictis, tam in toto quam in parte nisi de licentiâ supradicti Sir Walteri \& consorta eius. Atque in me suscepi pro me \& pro Asti Mister \& pro hæridibus Abrami supradicti quondam Mariti eius, \& pro omnibus hæredibus nostris \& posteris nostris warantisare, defendere, \& acquitare omnia debita supradicta tam quoad capitale quam quoad lucrum quod emersit usque ad diem facti contractûs huius supradicto Sir Waltero, \& hæredibus eius coram omnibus Iudæis hero sive viro sive fæminâ \& coram omni homine. Actum die quartâ in septimana Pentecostes Anno quinquagesimo secundo Regni supradicti. Atque hoc quod confessus sum sigillo meo munivi, Jose filius Bendit. Bendit filius Jose Testis. Chajim de Nikol [i.e. Lincoln] Testis.

The second deed: $:^{27}$

Ego infra scriptus confiteor confessione perfectâ me dimississe et cessisse Sir Waltero (Hebr. Gautier) de Merton, quondam Cancellario Domini nostri Regis, et hæredibus eius et posteris eius totum ius \& postulationem, quæ erat mihi vel potuit esse mihi super fundos \& tenementa \& appartenentias quas supradictus Sir Walterus tenet nunc ex Willelmo de Leicestre in oppido de Gamelegeye; ita ut neque ego, neque quicquam [sic] ex hæredibus Abrami filii Vives quondam Mariti Asti Montier, neque ullus ex posteris nostris, nos (inquam) non possimus postulare et contendere pro supradictis fundis \& tenementis \& appartenenciis

26 St John's College Oxford, MS No. 253, item 51, fo $63^{\mathrm{r}}{ }^{-}-63^{\mathrm{v}}$ ult.

27 Ibid., fo $63^{\mathrm{r}} 1 \mathrm{ffr}$. 
ullâ postulatione debiti, quavis causâ aut prætextu debiti, quod supradictus Willelmus de Leicestre et Gameleye debere possit supradicto Abramo vel Asti Montier, aut mihi, vel hæredibus meis a creatione mundi usque ad finem eius. Quod si reperiatur sigillum, vel diploma, vel quicunque alius actus sub nomine supradicti Willelmi de Leicestre, \& Gameleye, et nomine supradicti Abrami vel Asti Montier vel nomine meo aut cuiuscunque ex hæredibus nostris facta ante factum hunc contractum, profiteor illa esse irrita et cassa reputentur. quia Sir Walterus supradictus mihi rationem fecit omnium debitorum, quæ supradictus Willelmus debebat supradicto Abramo vel Asti Montier a creatione mundi usque finem eius. Et suscepi in me tam pro meipso quam pro hæredibus meis warantisare, defendere, \& acquitare ${ }^{[63 \mathrm{v}]}$ omnes fundos $\&$ tenementa $\&$ appartenentias supradictas, quæ pertinebant ad supradictum Willelmum, ut supradictus Sir Walterus teneat illa nunc contra omnes Iudæos, qui sunt in mundo sive vir sive fæmina, qui possent repetere quodvis debitum adversus supradictum Willelmum sub sigillo, vel Diploma, vel quolibet alio Actu a creatione mundi usque ad finem eius. Atque id quod confessus sum sigillo meo munivi Jose filius Bendit. Bendit filius Jose Testis. Chajim de Nikol (Lincoln) Testis.

His translation, written in the scholarly Latin of the time, is mostly correct. There are, however, some oddities. Gagnier transcribes אשתי (my wife) as 'Asti'; he took the word as a proper name rather than a simple noun. The reason for this would seem to be that he had trouble with expressions like בעל אשתי (the husband of my wife), and did not realise that Esther, the wife, remarried after the death of her first husband. Likewise, the similarity of and $\boldsymbol{w}$ in the script of the starrs let Gagnier to transcribe the name 'Esther' as 'Mister'. He translates חתמת as 'sigillo munivi'; however it does not mean 'I sealed', but rather 'I signed'. There is no seal on the document, and Jews did not normally seal their documents. ${ }^{28}$

\section{IV}

These Hebrew deeds or starrs illustrate only one legal aspect of Walter de Merton's buying the land in Gamlingay. While he had to make sure that there were no claims by any Jew to the land he was about to purchase, there were other considerations he also had to take into account. The Christian landowner who originally borrowed the money form the Jewish money-lender and mortgaged his land in the process also had to cede all claims to his former property. In the case of the present transaction, it is William of Leicester who wrote the corresponding Latin quitclaim, a document which, as we have seen, was originally stored together with the Hebrew deeds. In this Latin quitclaim, William of Leicester declares that he has transferred to Walter de Merton his title to the land in Gamlingay together with all appurtenances and the advowson of the village church, while keeping eighteen pence rental income which William's sister Primula used to enjoy, and six acres of land set aside for his brother Paschasius. Unlike its Hebrew counterparts, the original Latin deed

28 An exception is Jacob, the Jew's seal is described in Highfield, Early Rolls, (as in n. 6 above), p. 406 . 


\section{never left Merton. ${ }^{29}$ Text and translation follow:}

Omnibus Christi fidelibus ad quos presens scriptum peruenerit Willelmus de Leycestre de Gamelegeye salutem in domino. Sciatis me dedisse concessisse et hac carta mea confirmasse amico meo dilecto domino Waltero de Merton illustris domini Henrici Regis Anglie quondam cancellario totam terram meam in Gamelegeye cum aduocacione medietatis ecclesie eiusdem uille et cum omnibus aliis ad predictam terram spectantibus siue in dominicis redditibus seruiciis consuetudinibus seu quibuscumque rebus aliis absque ullo retinemento exceptis decem et octo denariis redditus quas [sic] soror mea Primula michi reddere consueuit de tenemento quod de me tenet in Gamelegeye et homagio Paschasii fratris mei et sex acris terre quas ad opus eiusdem fratris mei retinui. habendum et tenendum de me et heredibus meis eidem domino Waltero ad totam uitam suam et post decessum eiusdem domini Walteri domui scolarium de Merton quam idem dominus Walterus apud Maldon in comitatu Surr' ad perpetuam sustentationem scolarium in scolis degentium et ministrorum altaris Christi in dicta domo commorantium nuper fundauit. necnon scolaribus et fratribus dicte domus. faciendo inde capitalibus dominis feodi pro me et heredibus meis seruicia inde debita et consueta que ego ipse facere consueui et debui pro omni seruicio secta curie consuetudine et demanda in perpetuum. uolo igitur et concedo pro me et heredibus meis quod predictus dominus Walterus ad totam uitam suam et post decessum eiusdem domini Walteri scolares et fratres predicti in perpetuum habeant et teneant de me et heredibus meis totam terram meam predictam in Gamelegeye cum aduocacione medietatis ecclesie eiusdem uille et cum omnibus aliis ad predictam terram spectantibus siue in dominicis redditibus seruiciis consuetudinibus uillenagiis seu quibuscumque rebus aliis absque ullo retinemento exceptis decem et octo denariis redditus quas [!] soror mea Primula michi reddere consueuit de tenemento quod de me tenet in Gamelegeye et homagio Paschasii fratris mei et sex acris terre quas ad opus eiusdem fratris mei retinui. faciendo inde capitalibus dominis feodi pro me et heredibus meis seruicia inde debita et consueta que ego ipse facere debui et consueui. pro omni seruicio secta curie consuetudine et demanda in perpetuum sicut predictum est. et ego prefatus Willelmus et heredes mei totam terram predictam cum pertinenciis eidem domino Waltero ad totam uitam suam et post decessum eiusdem domini Walteri dicte domui scolarium de Merton et scolaribus et fratribus eiusdem domus per predicta seruicia contra omnes gentes warantizabimus acquietabimus et defendemus. in perpetuum. et ad maiorem huius rei securitatem presenti scripto sigillum meum apponi feci. his testibus domino Johanne de Kyrkeby,Waltero de Odiham, Rogero de Donecastro, Thoma Tayllard, Rogero fratre eius et Ricardo de la More de comitatu Buckingahamscire. Johanne Pesemer et Thoma de Mackneye de comitatu Berrscire. Johanne de Herierd et Nicholo de Thedden de comitatu Suhantunescire Ricardo de Brademer et Willelmo Dudekyn de comitatu Surr' et aliis.

\section{Translation:}

To all Christians to whom the present deed comes, William of Leicester says greetings in the Lord. Know that I have given, granted and by this my charter

29 Merton College, Oxford, Archives, 2349 (cf. Stevenson's Calendar, vol. 5, Cambridgeshire p. 36). There is a copy of this document (2350), and a final concord (2353) dating to 1 July 1268 which completes the conveyance (cf. Stevenson, Calendar, 5.37-38). See section I above for a full discussion. 
confirmed to my beloved friend Walter de Merton, former chancellor of the famous Lord Henry, King of England, all my land in Gamlingay, with the moiety of the advowson of the church of the same village, and all other things regarding the aforementioned land, be it demesnes, rents, services, customs, or any other things, without any reservation; except eighteen pence rent which my sister Primula used to give me [as income] from the tenement which she holds of me in Gamlingay; [and except] the homage of my brother Paschasius; and [except] the six acres of land which I kept for the benefit of the same brother; [all these things I give] to have and to hold of me and of my heirs to the same Lord Walter for all his life, and after the death of the same Walter to the house of scholars de Merton which the same Lord Walter has recently founded near Malden in the county of Surrey in order to support the scholars living in the schools and the servants of the altar of Christ dwelling in the recently founded aforementioned house, as well as to the scholars and brethren of the aforementioned house; by rendering to the chief lords of the fee in my and my heirs' stead, in perpetuity, the services which are due and accustomed therein, which I was accustomed to do and to owe for all services of suit of court, custom and demand; I wish therefore and concede, for myself and my heirs, that the aforementioned lord Walter for his entire life, and after the death of the same lord Walter the aforementioned scholars and brethren, shall have and hold in perpetuity of me and of my heirs all my aforementioned land in Gamlingay, with the advowson of moiety the church of the same village and with all other rights pertaining to the said land whether in demesnes, rents, services, customs, villeinages or any other renders whatsoever, without any reservation except 18 pence in rent which my sister Primula is accustomed to render to me from the tenement that she holds of me in Gamlingay and except the homage of Paschasius my brother and six acres of land which I retained to the use of that same brother, doing therein to the chief lords of the fee for me and my heirs the services owed and accustomed therein which I myself was obliged and accustomed to do for all service of suit of court, custom and demand in perpetuity as is aforesaid. And I, the aforementioned William, and my heirs warrant, acquit and defend against all people [this grant of] my entire aforesaid land with appurtenances to the same lord Walter for his entire life and after his death to the said house of the scholars of Merton and to the scholars and brethren of the same house of the same Walter. And for the greater security of this matter I have had my seal appended to the present writing, before these witnesses: John de Kirkby, Walter de Odiham, Roger de Doncaster, Thomas Tayllard, Roger, his brother, Richard de la More, from the county of Buckinghamshire, John Pesemer, Thomas de Mackney, from the county of Berkshire, John de Herriard, Nicholas de Thedden from the county of Hampshire, Richard de Brademer and William Dudekyn, from the county of Surrey and others.

Although Jews were never members of the University of Oxford in the formal sense during the Middle Ages, they were involved in some aspects of the students' and scholars' life. ${ }^{30}$ Jews lent money to students who, not unlike nowadays, were often hard pressed for cash. Some of the students even used

${ }^{30}$ I draw heavily on Roth, The Jews of Medieval Oxford (as in n. 1 above), ch. 7. 
their textbooks as deposits although this practice was later prohibited and prosecuted. As time went by, the Jews were more and more hampered in the exercise of their professional activities, especially during the second half of the thirteenth century; money-lending became increasingly restricted. ${ }^{31}$ But there was one area in which Jews continued to play an important role at least until the early 1270s: the rental market. Housing was a problem in the buzzing university town, and some Jews were quite prominent landlords. The most famous was Jacob, son of Rabbi Moses of London, from whom Walter de Merton bought some properties.

Despite this active role within the life of the university, Jews came under mounting pressure from different quarters. The theological and political rhetoric against them developed to such an extent that some modern scholars talk about medieval English antisemitism. ${ }^{32}$ Yet Jews were also the victims of growing legal uncertainty, and often forced to sell their possessions. R. S. Stacey poignantly described this situation: ${ }^{33}$

To pay their taxes, Jews were forced either to hand over their uncollected bonds directly to the crown, or else to sell the bonds 'short' on the open market. Either way, the bonds tended to wind up in the hands of King Henry's own friends and relations, who promptly foreclosed upon the Christian debtors.

Walter de Merton was one of those close enough to the king to profit from this legal uncertainty, if not personally, then at least for the benefit of his new foundation. He was a shrewd and astute businessman who had as the chancellor of the king gained substantial experience in legal matters. He had, more specifically, an intimate knowledge of the Court of Exchequer of the Jews, and this allowed him to spot many of the precarious debts alluded to above. $^{34}$

Therefore, Walter de Merton, being concerned about endowing his foundation, 'the House of the Scholars de Merton', as best he could, bought up many of these debts, often from people who had found themselves on the wrong side during the Civil War when Henry III's son Edward (later king Edward I), defeated Simon de Montfort. In the present case, William of Leicester was unable to pay back debts which were originally due in 1262 and 1263 , that is to say on the eve of the war for reason unknown to us; in 1268 William was so desperate that he sold, or was forced to cede, his own land, keeping only the small sources of income which were allocated to his siblings, his sister Primula and his brother Paschasius. We can only speculate why Abram, son of Vives, the original creditor, and his successor Josce, son of Bendit, allowed William not to repay his debts for the five years or so from when they were due

31 Cf. R. R. Mundill, England's Jewish Solution: Experiment and Expulsion, 1262-1290 (Cambridge University Press, Cambridge, 1998), ch. 4, entitled 'The Attempted Prohibition of Usury and the Edwardian Experiment'.

32 E.g. R. S. Stacey, 'Antisemitism and the Medieval English State', in J. R. Maddicott and D. Palliser (eds), The Medieval English State: Essays Presented to James Campbell (Hambleton Press, London/Rio Grande, 2000), pp. 163-77; cf. also J. Cohen, The Friars and the Jews: the Evolution of Medieval Anti-Judaism (Cornell University Press, Ithaca/London, 1982).

33 Ibid., p. 173.

${ }^{34}$ Cf. Highfield, Early Rolls (as in n. 6 above), pp. 34-36. 
originally, although this may have had to do with the increasing difficulties in collecting debts which Jews experienced from the 1250s onwards.

The timing of these transactions is also interesting in another respect. Just six days before the date of the first deed, there was a certain amount of upheaval in Oxford. ${ }^{35}$ On Ascension Day, 17 May 1268, the Chancellor had led a procession of university students and staff through Oxford carrying a cross. Allegedly, a Jew, who is not named in any of the sources, snatched the cross and smashed it; turmoil followed, and the Christian population ransacked a number of Jewish houses. The Jews were then all put in jail, and ordered to pay compensation for the destroyed cross. The only Jews who escaped these measures were Jacob, son of Moses, of Oxford, and his sons who all happened to be in London during the incident. Like Jacob, who often did business with Walter de Merton, ${ }^{36}$ Josce, son of Bendit, was also in London. Although there is no solid evidence, one can speculate about whether the selling of a bad debt by a Jew in London (Josce, son of Bendit) to Walter de Merton is linked to these events. Certainly the possibility cannot be ruled out that Walter struck some sort of deal offering protection to his Jewish trading partner in return for cheap land.

The legal side of this transaction, as far as William of Leicester is concerned, is brought to a close on 1 July 1268 with a final concord confirming the conveyance. ${ }^{37}$ Yet this is not the last time we hear of this purchase. In a second version of the statutes of Merton College, dating back to 1270, Walter mentions his possessions in Gamlingay; this is one of the new possessions not included in the first version. ${ }^{38}$ Furthermore, there is an entry in the plea rolls of the Exchequer of the Jews for the year 1272. Rigg translated the entry in the following way: ${ }^{39}$

Walter de Merton, by his attorney, offered himself on the fourth day against Josce, son of Benedict, touching a plea, that he acquit him as to the King of Germany of $£ 80$ demanded of him to the use of the said King on account of Abraham, son of Vives. Walter, ${ }^{40}$ being already under distraint, makes default

35 For these events cf. Roth, The Jews of Medieval Oxford (as in n. 1 above), pp. 151-54; and Highfield and Martin, History of Merton College (as in n. 13 above), pp. 31-34; Chr. Cluse, 'Stories of Breaking and Taking the Cross: a Possible Context for the Oxford Incident of 1268', Revue d'Histoire Ecclésiastique 90 (1996), pp. 396-442, explores the intellectual climate in which this incident happened.

${ }^{36}$ One example for such dealings is illustrated in the deed of conveyance for Halegod's House which Jacob signed in Hebrew by his own hand and which is reproduced in P. S. Allen and H. W. Garrod, Merton Muniments (Oxford Historical Society, Oxford, 1928), no. 5a; see also n. for the seal.

37 See n. 29 above.

38 Cf. Highfield and Martin, History of Merton (as in n. 13 above), p. 17.

39 J. Rigg, Calendar of the Plea Rolls of the Exchequer of the Jews preserved in the Public Record Office, vol. I: Henry III, 1218-1272 (Macmillan, London, 1905), pp. 280-81.

40 My italics; this is a mistake by Rigg. Josce is already under distraint. Cf. the summary in H. G. Richardson, Calendar of the Plea Rolls of the Exchequer of the Jews preserved in the Public Record Office and the British Museum, vol. 4 (continuation of Rigg, previous note) (Macmillan, London, 1972), no. 29: 'York-Walter of Merton appeared against Josce son of Benedict, Jew, for acquittance of $£ 80$ demanded on behalf of the King of Almaine in respect of a debt of Abraham son of Vives, Jew. Defendant did not appear. Sheriff returned that he is not in York, but in London. Adjourned until three weeks after Michaelmas.' 
of appearance; wherefore mandate to the Sheriff as before, that keeping safe, $\& c$., the chattels to the value of 20 s, by which he had distrained him, he distrain by more chattels, if more he may find, \&c. and have his body before \&c. The Sheriff sends word that the said Josce is not at York, but at London, and therefore nothing is done. Wherefore as before, for Michaelmas three weeks.

This is rather difficult legal prose. The preceding English translation of the original Latin Plea Roll means the following: Walter's attorney brings an action against Josce, son of Bendict (or Bendit). Walter demands that Josce pay $£ 80$ to the king of Germany (i.e. King Henry III's brother Richard of Cornwall). The $£ 80$ correspond, with interest accrued, to the sum of money paid for the properties in Gamlingay. Previously, Richard, who had been promised the possessions of the Jewry in 1262, had brought an action against Walter, probably because Richard had a claim to the possessions of Abraham (or Abram), son of Vives. Richard alleged that the land in Gamlingay belonged to him, and that Josce, son of Bendict, had had no right to sell it to Walter de Merton, since he (Richard) had a claim to it. But as the starrs published here show, Josce had pledged that there was no other claim on the land in Gamlingay. Therefore Walter de Merton wanted Josce to pay the debt to Richard and thereby warrant him (Walter) his possessions, as he (Josce) had pledged to do in the deed of conveyance. Josce was already under distraint in a different matter. Josce did not appear in court, his assets could not be seized by the Sheriff, because Josce was in London, not in York where the action was brought.

Based on the error by Rigg mentioned above (n. 40), Roth ${ }^{41}$ interpreted the text differently: 'it must be another Walter de Merton, I think, ...', that is to say, he thought that the former chancellor would hardly have been under distraint. But given the content of the Hebrew deeds published here, it cannot be disputed that the Walter de Merton mentioned in the plea roll is the founder of Merton College. This legal action, brought on the basis of the deeds of conveyance published here, hints at, and forebodes, the difficult legal and economic situation in which the Jews in England found themselves in the 1270 s and 1280 s, finally leading to their expulsion. ${ }^{42}$

Walter de Merton himself restricted the ability of the Jews to lend money further and further from January 1269, and the Jews finally lost their ability to rent out property altogether in $1271 .{ }^{43}$ So it is clear that they were put under ever increasing constraint from different quarters, while Walter de Merton and his foundation continued to prosper. Another 20 years and the Jews would have to leave the country altogether, while the 'first English college to

41 The Jews of Medieval Oxford (as in n. 2), pp. 141-42.

42 Although this might 'smack of teleology' as Cluse, 'Stories' (as in n. 35), p. 404, rebukes Roth, I still think that the decline in the economic and social position of the Jews leads to, and is a sign for, their later ordeal. The situation of the Jews under Edward I is admirably described in R. R. Mundill, 'Edward I and the Final Phase of Anglo-Jewry', in P. Skinner, The Jews in Medieval Britain: Historical, Literary and Archaeological Perspectives (Boydell Press, Woodbridge, 2003), pp. 55-70.

43 Ibid., pp. 151, 155; cf. Mundill, England's Jewish Solution (as in n. 31), pp. 41, 58-59. 
exist de jure as well as de facto, ${ }^{44}$ in the foundation of which the Jews were indirectly involved, turned out to be the model for most other Oxford and Cambridge colleges. ${ }^{45}$ The documents published here thus bear witness to the participation of the Jews, be it modest, in the emergence of the collegiate system in Oxford.

44 D. R. Leader, A History of the University of Cambridge, i: The University to 1546 (Cambridge University Press, Cambridge, 1988), p. 60.

45 Cf. M. Rubin, Charity and Communbity in Medieval Cambridge (Cambridge University Press, Cambridge, 1987), pp. 273-76; Highfield and Martin, History of Merton (as in n. 13 above), p. 1. 